\title{
Detection of Epstein-Barr virus in different sources of materials from patients with oral lichen planus: a case-control study
}

\author{
Rúbia da Rocha Vieira, ${ }^{1}$ Lígia Lavezo Ferreira, ${ }^{1}$ Éder Ricardo Biasoli, ${ }^{1}$ \\ Daniel Galera Bernabé, ${ }^{1}$ Cáris Maroni Nunes, ${ }^{2}$ Glauco Issamu Miyahara ${ }^{1}$
}

\begin{abstract}
${ }^{1}$ Oral Oncology Center and Department of Pathology and Clinical Propaedeutics, Araçatuba School of Dentistry, Araçatuba, São Paulo, Brazil ${ }^{2}$ Animal Health and Production, Araçatuba School of Veterinary Medicine, Araçatuba, São Paulo, Brazil
\end{abstract}

\section{Correspondence to} Glauco Issamu Miyahara: Oral Oncology Center Araçatuba Dentistry School, Univ Estadual Paulista José Bonifácio street, 1.193 zip code 16015-050 - Araçatuba, São Paulo State, Brazil; miyahara@foa.unesp.br

Received 7 August 2015 Revised 22 September 2015 Accepted 23 September 2015 Published Online First 14 October 2015

\section{ABSTRACT}

Aims To detect the presence of Epstein-Barr virus (EBV) DNA in different sources of materials from a matched group of patients with oral lichen planus (OLP) and a group of people without OLP lesions, and to correlate the presence of virus with epidemiological variables of the groups studied.

Methods Fresh tissue samples, saliva, exfoliated cells and plasma of 24 patients with OLP lesions (cases) and 17 patients without OLP lesions (controls) were collected. EBV was detected by nested PCR.

Results Viral positivity was obtained in $62.5 \%$ of tissue samples; in $70.8 \%$ of exfoliated cell samples; in $33.3 \%$ of blood plasma samples and in $75 \%$ of saliva samples in the cases; and in $35.3 \%$ of tissue samples; $82.4 \%$ of exfoliated cell samples; in $47.1 \%$ of blood plasma samples and in $64.7 \%$ of saliva samples in the controls. There was a predominance of women in both groups. Variables not atrophic-erosive were most affected by EBV.

Conclusions No relationship between EBV and OLP was found. However, all sources tested in this study were considered suitable for the detection of viruses.

\section{INTRODUCTION}

Oral lichen planus (OLP) is a chronic inflammatory autoimmune disease, ${ }^{1}$ which affects around $2-3 \%$ of the population, ${ }^{2}$ with middle-aged women being the most affected. ${ }^{3}$ Its aetiology is uncertain, but it is thought to be a multifactorial process involving genetic, psychological and infectious factors. ${ }^{4}$ Included in the group of infectious factors are hepatitis $C$ virus, ${ }^{5}$ herpes simplex virus (type 1 ), human herpes virus (type 6), ${ }^{67}$ human papillomavirus and Epstein-Barr virus (EBV). ${ }^{8}$ OLP presents six variations, including the reticular, plaque, papular, atrophic, erosive and bullous types. ${ }^{9}$ Diagnosis is made by the clinical appearance of the lesion and is subsequently confirmed by biopsy and histopathological analysis of the specimen, ${ }^{10}$ which presents with hydropic degeneration of the basal layer and lymphocytic infiltration in the subepithelial layer. ${ }^{11}$

It is usually treated with topical steroids, systemic steroids and immunosuppressive agents. ${ }^{12}$ EBV belongs to the Herpesviridae family and subfamily gammaherpesviridae. It has double-stranded DNA contained in an icosahedral nucleocapsid consisting of 162 capsomers and houses a viral genome DNA of approximately $172000 \mathrm{bp} .{ }^{13} 14$

Until now, EBV has been known as the most potent cell immortalisation virus, infecting about
$90 \%$ of the adult population with the asymptomatic form. ${ }^{15}{ }^{16}$ It is responsible for the development of infectious mononucleosis, hairy leukoplakia and some malignancies, such as Burkitt's lymphoma, non-Hodgkin lymphoma and nasopharyngeal carcinoma. ${ }^{17}$

It has two subtypes: type 1 , which affects mainly the Asian and Caucasian populations and type 2, which is more often found in the African population. ${ }^{18}$ It is primarily transmitted by oral contact in the acute phase of the disease, mainly affecting the epithelial cells of the oropharynx and salivary glands, which are susceptible to infection, with periodic replication and elimination of the virus through saliva. ${ }^{19-21}$ Subsequently, it affects the B lymphocytes (target cells of the virus), where a small fraction of these cells act as a reservoir for EBV, after primary infection. ${ }^{22}{ }^{23}$ After the virus penetrates the cell, two possible forms of infection may occur: lytic infection, in which the EBV DNA is incorporated into the lymphocyte genome, and is replicated and transcribed in the nucleus; and latent infection, which occurs after the initial infection, in which the viral DNA in the nucleus remains episomal, and the lymphocyte DNA is circular. ${ }^{14}$ Stress and immune deficiency are factors leading to reactivation and replication of the virus. ${ }^{24}$

The correlation between EBV and OLP has been the focus of many studies, in which several techniques for EBV detection have been used, among them immunohistochemistry, in situ hybridisation, PCR and nested PCR (nPCR). PCR is one of the most commonly used methods in various areas of molecular diagnostics, owing to its great ability to detect small fragments of DNA. nPCR is a variation of the PCR technique, involving two stages of DNA synthesis. The material produced in the first step is used in the second step, with the aim of attaining specificity and efficiency of target DNA amplification. ${ }^{25}$

Cruz $e a^{15}$ used PCR to investigate the correlation between EBV in patients with and without potentially malignant lesions. Correlation was found between EBV and the presence of potentially malignant lesions (77.8\%); however, it was also found in $8.3 \%$ of controls. Sand et al, ${ }^{26}$ using nPCR, analysed the presence of EBV in paraffin-embedded tissue samples from 23 patients with OLP, and 67 controls without OLP. The virus was found in $26.1 \%$ of samples from patients with OLP and in $7.3 \%$ of samples from the controls.

In view of the differing reported results for the existence of a correlation between EBV and OLP, the 
Figure 1 Prevalence of affected regions in the studied groups.
- Buccal mucosa Tongue dorsum a Tongue edge alveolar ridge

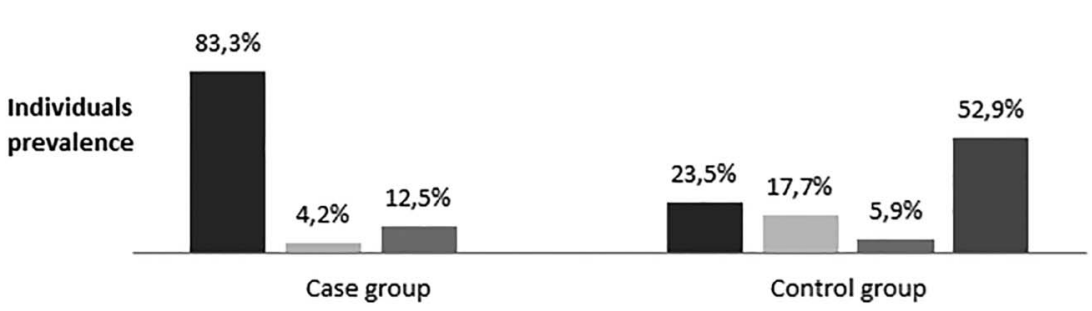

aim of this study was to investigate the relationship between this virus and OLP using nPCR, in different sources of materials (fresh tissue, blood plasma, saliva and oral exfoliated cells) of a matched group of patients with and without OLP lesions. In addition, the aim was to correlate the epidemiological data of the groups studied with the presence of virus, and verify whether the sources of material tested in this study are suitable for EBV detection. It is important to emphasise that we found no studies which had reported the presence of EBV in samples of tissue exfoliated cells, saliva and plasma of patients with OLP lesions. Therefore, this is the first case-control study, matched for sex and age, which involves the detection of EBV in different sources of materials from a group of patients with and without OLP lesions.

\section{MATERIALS AND METHODS Inclusion criteria}

As this was a case-control study with paired groups, it was necessary for all the patients in the two groups to be of the same sex, and similar age, with at most $\leq 3$ years of difference. Based on this, 24 patients with a histological diagnosis of OLP obtained by the same pathologist (cases); and 17 patients without suspicion of OLP requiring distal wedge or pre-prosthetic surgery (controls) were selected and included in this study.

\section{Exclusion criteria}

Excluded from this study were people who had any type of infection, fever, kidney disease, diabetes, autoimmune diseases, were pregnant, and those who had been treated for any malignancy, or who were using the following drugs: antiinflammatory drugs (past 3 months), antibiotics (past 6 months), contraceptives, antidepressants, immunosuppressants and chemotherapeutic agents.

\section{Ethical considerations}

This study was approved by the research ethics committee of the institution at which the study was conducted. All patients in this study provided free and informed written consent.

\section{Data collection and materials \\ Cases}

- Biopsies were performed for diagnostic purposes and the material obtained was divided into two parts. One part was preserved in $10 \%$ buffered formalin and sent for histopathological examination by haematoxylin and eosin staining. The other part was stored at $-80^{\circ} \mathrm{C}$ and used for biomolecular EBV DNA detection tests.

- For saliva and exfoliated cell collection patients were instructed not to consume any food or drink for 30 min before the collection. To obtain saliva samples, patients were asked to spit into a $15 \mathrm{~mL}$ Falcon tube for a period of 5-10 min in order to obtain at least $5 \mathrm{~mL}$ of saliva.

- Exfoliated cells were collected by means of a cytological brush, which was firmly rubbed and rotated in the lesion 5-10 times. After this the OLP specimens were individually stored in $2 \mathrm{~mL}$ polypropylene tubes containing $300 \mu \mathrm{L}$ of Mili-Q water or tris (hydroxymethyl)aminomethane and ethylenediamine tetraacetic acid (EDTA). The samples of saliva and exfoliated cells were distributed in $2 \mathrm{~mL}$ polypropylene tubes, identified and stored at $-80^{\circ} \mathrm{C}$ for later laboratory procedures

- Blood $(10 \mathrm{~mL})$ was collected in a $50 \mathrm{~mL}$ Falcon tube, containing $0.2 \mathrm{~mL}$ of $10 \%$ EDTA trisodium. After collection, the samples were immediately centrifuged to obtain plasma, and then placed in $2 \mathrm{ml}$ polypropylene tubes, identified and stored at $-80^{\circ} \mathrm{C}$.

\section{Controls}

Material collection from controls was carried out by the same techniques as used for the cases, except for biopsies, which were performed as a treatment modality, and collection of exfoliated cell samples, which was performed in a normal region of the controls.

\section{PCR for control human gene}

To perform the PCR for $\beta$-globin gene amplification we used the PCO 3 and PCO 4 oligonucleotides with $110 \mathrm{bp} .^{27}$ The reaction mix comprised $2.5 \mu \mathrm{L}$ of $10 \times$ PCR buffer (Tris- $\mathrm{HCl} 10 \mathrm{mM}, \mathrm{pH}$ 8; KCl $50 \mathrm{mM}$ ) (Invitrogen Life Technologies, Brazil), $0.75 \mu \mathrm{L}$ $\mathrm{MgCl}_{2}$ (Invitrogen, Life Technologies, Brazil), $1.5 \mu \mathrm{L}$ deoxyribonucleoside 5'-triphosphate (dNTP) mix-deoxyadenosine triphosphate (dATP), deoxycytidine triphosphate (dCTP), deoxyguanosine triphosphate (dGTP), deoxythymidine triphosphate (dTTP)) (Healthcare, USA), $1.5 \mu \mathrm{L}$ Taq DNA polymerase (Invitrogen, Life Technologies, Brazil), $1.5 \mu \mathrm{L}$ of each oligonucleotide (Invitrogen, Life Technologies, Brazil), $5 \mu \mathrm{L}$ of
Figure 2 Result of $\beta$-globin amplification (110 bp) in tissue samples from cases (A) and controls (B). MW, molecular weight (50 bp); NC, negative control (without DNA); $P C$, positive control (DNA from human blood).

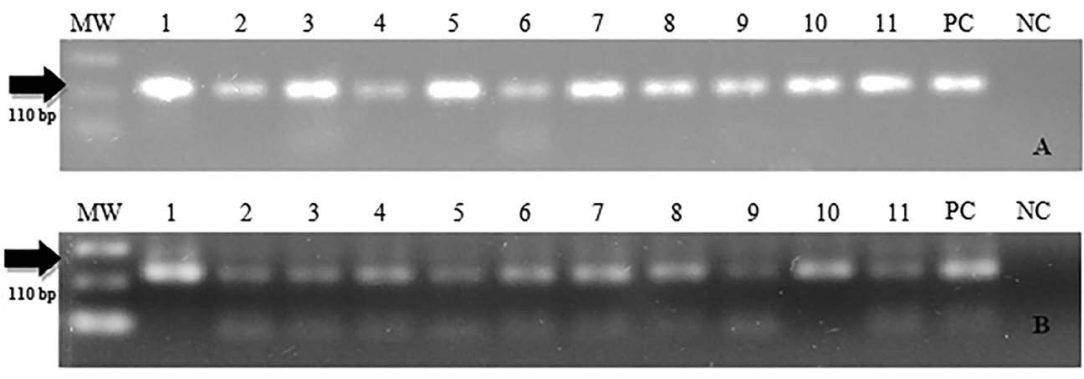


Figure 3 Amplification of EpsteinBarr virus (EBV) (100 bp) by nested $P C R$ in saliva samples of 12 cases. $\mathrm{MW}$, molecular weight (50 bp); $\mathrm{NC}$, negative control (without DNA); PC, positive control (DNA extracted from Hodgkin's lymphoma).
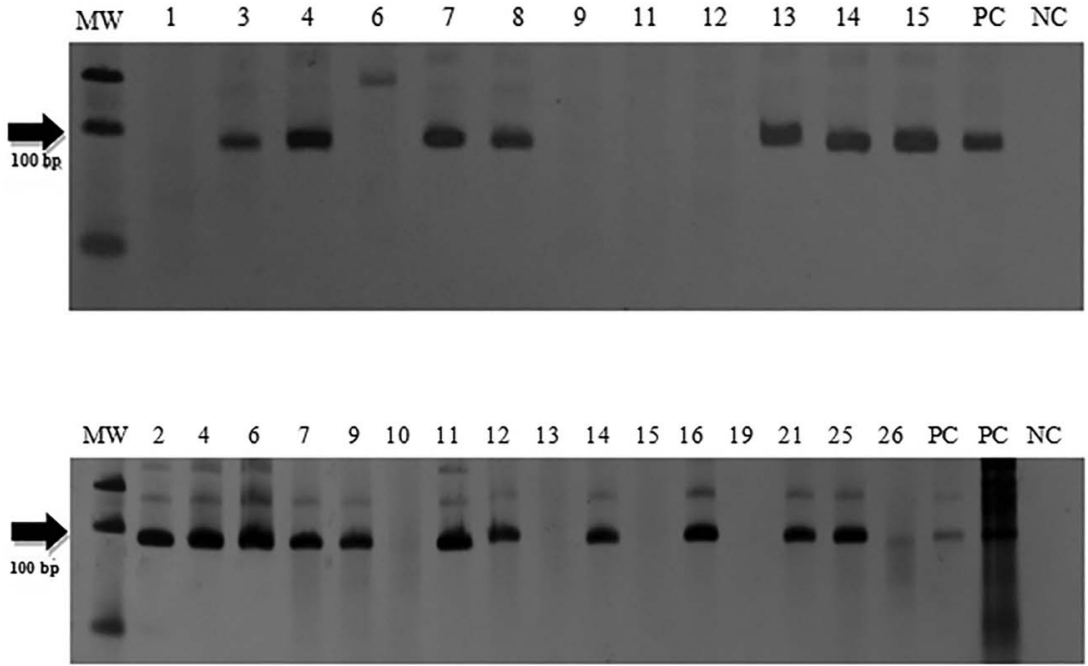

Figure 4 Amplification of EpsteinBarr virus (EBV) (100 bp) by nested PCR in saliva samples of 16 controls. $\mathrm{MW}$, molecular weight (50 bp); NC, negative control (without DNA); PC, positive control (DNA extracted from Hodgkin's lymphoma). genomic DNA sample and ultrapure water (Invitrogen, Life Technologies, USA) to give a final volume of $25 \mu \mathrm{L}$.

The amplification reactions were carried out in a thermocycler (Peltier Effect Cycling PTC model-100, MJ Research, USA) under the following conditions: initial denaturation at $95^{\circ} \mathrm{C}$ for $10 \mathrm{~min}, 35$ cycles of denaturation at $95^{\circ} \mathrm{C}$ for $1 \mathrm{~min}$, annealing at $55^{\circ} \mathrm{C}$ for $1 \mathrm{~min}$ and extension at $72^{\circ} \mathrm{C}$ for $2 \mathrm{~min}$, with final extension at $72^{\circ} \mathrm{C}$ for $8 \mathrm{~min}$. For tissue and plasma samples, the annealing temperature was changed to $53^{\circ} \mathrm{C}$ and $50^{\circ} \mathrm{C}$, respectively.

The presence of human DNA was checked by electrophoresis on $2 \%$ agarose gel in $1 \times$ tris-borate-EDTA buffer (Source Electrophoretic-Amersham Pharmacia Biotech-model EP3501, Sweden). The bands were visualised under ultraviolet light after staining with ethidium bromide, and then photographed using the Kodak Digital Science 1D system (Eastman Kodak Company, USA).

To confirm the presence and integrity of genomic DNA, the samples were searched for genes of EBV.

\section{$\mathrm{nPCR}$ for amplification of EBV}

The amplification mix comprised $2.5 \mu \mathrm{l}$ of $10 \times$ PCR buffer (Tris- $\mathrm{HCl} 10 \mathrm{mM}, \mathrm{pH} 8 ; \mathrm{KCl} 50 \mathrm{mM}$ ) (Invitrogen, Life Technologies, USA), $1.3 \mu \mathrm{L} \quad \mathrm{MgCl}_{2}$ (Invitrogen, Life Technologies, USA), $0.2 \mu \mathrm{L}$ of each dNTP (dATP, dCTP, dGTP, dTTP) (Amershan Biosciences, USA), $0.5 \mu \mathrm{L}$ Taq DNA polymerase (Invitrogen, Life Technologies, Brazil), $0.5 \mu \mathrm{L}$ of each oligonucleotide that forms part of the BamHIW region of EBV (external oligonucleotide forward-GAGACCGAAGTGAAGT CCCT, external oligonucleotide back-GGTGCCTTCTTA GGAGCTGT, internal oligonucleotide forward-GCCAGAGG
TAAGTGGACTTTAAT, internal oligonucleotide back-GAG GGGACCCTGAGACGGGT) (Integrated DNA Technologies, USA), $5 \mu \mathrm{L}$ of genomic DNA sample and ultrapure water (Invitrogen, Life Technologies, USA) to give a final volume of $50 \mu \mathrm{L}$.

The amplification reactions were carried out in a thermocycler (Peltier Effect Cycling PTC model-100, MJ Research, USA) under the following conditions: 1 cycle of initial denaturation at $94^{\circ} \mathrm{C}$ for $2 \mathrm{~min}, 35$ cycles of denaturation at $94^{\circ} \mathrm{C}$ for $30 \mathrm{~s}, 35$ cycles of annealing at $55^{\circ} \mathrm{C}$ for $30 \mathrm{~s}, 35$ cycles of extension at $72^{\circ} \mathrm{C}$ for $30 \mathrm{~s}$, followed by 1 cycle of final extension for $5 \mathrm{~min}$ at $72^{\circ} \mathrm{C}$. In the second step of the nPCR, the initiating oligonucleotides amplify a $100 \mathrm{bp}$ fragment within the sequence of the amplified fragment in the first step. For this purpose, we used a $1 \mu \mathrm{L}$ sample of the DNA product obtained in the first step. The amplification mix and cycling conditions were the same as those used in the first step, except for substitution of external oligonucleotide by the internal oligonucleotide.

DNA extracted from the Hodgkin's lymphoma sample and the mix of components used for DNA amplification, were used as positive and negative controls, respectively.

The nPCR products were subjected to electrophoresis in $8 \%$ polyacrylamide gel for $2 \mathrm{~h}$ under constant voltage of $100 \mathrm{~V}$. The bands were visualised by staining with a silver nitrate solution and were then documented. All samples in this study were tested in duplicate.

\section{ANALYSIS OF RESULTS}

Data from each group were analysed with the software EPI INFO 7 V.7.1.3.0 (Centers for Disease Control and Prevention, USA) and Microsoft Office Excel 2007 (Microsoft, USA). To

Table 1 Case-control analysis of the presence and absence of EBV virus in each source material

\begin{tabular}{|c|c|c|c|c|c|c|c|}
\hline \multirow[b]{2}{*}{ Source } & \multicolumn{3}{|l|}{ Cases } & \multicolumn{3}{|l|}{ Controls } & \multirow[b]{2}{*}{$p$ Value } \\
\hline & $\mathrm{EBV}+(\%)$ & EBV- (\%) & Total (\%) & $\mathrm{EBV}+(\%)$ & EBV- (\%) & Total (\%) & \\
\hline Tissue & $15(62.5)$ & $9(37.5)$ & $24(100)$ & $6(35.3)$ & $11(64.7)$ & $17(100)$ & 0.0899 \\
\hline Saliva & $18(75)$ & $6(25)$ & $24(100)$ & $11(64.7)$ & $6(35.3)$ & $17(100)$ & 0.4808 \\
\hline Exfoliated cells & $17(70.8)$ & $7(29.2)$ & $24(100)$ & $14(82.4)$ & $3(17.6)$ & $17(100)$ & 0.4033 \\
\hline Blood plasma & $8(33.3)$ & $16(66.7)$ & $24(100)$ & $8(47.1)$ & $9(52.9)$ & $17(100)$ & 0.3806 \\
\hline
\end{tabular}


Table 2 Comparison of the proportions of EBV positivity in the cases and controls in each of the sources studied

\begin{tabular}{llll}
\hline Sources & Cases & Controls & p Value \\
\hline Tissue & 62.5 & 35.3 & 0.0859 \\
Saliva & 75.0 & 64.7 & 0.7940 \\
Exfoliated cells & 70.8 & 82.4 & 0.9652 \\
Blood plasma & 33.3 & 47.1 & 0.3748 \\
\hline Significance level of 5\%. & & & \\
EBV, Epstein-Barr virus. & & &
\end{tabular}

verify the correlation between the groups for the status of EBV in each source material, the $\chi^{2}-$ Mantel-Haenszel, and the Fisher exact tests were applied at a 5\% level of significance.

\section{RESULTS}

In this study, 24 patients with OLP (cases) and 17 patients without OLP (controls), matched for sex and age, with at most $\leq 3$ years of difference, were included.

The mean age of cases was 56.3 years (range 43-72; SD 7.8) and of controls 57.6 years (range 42-69; SD 9.1). At the level of $5 \%$, no significant difference was found between the ages of groups $(p=0.6171)$. Female subjects were most prevalent in both groups $(83.3 \%$ in the cases and $76.5 \%$ in the controls).

In the cases, the area most affected by OLP lesions was the buccal mucosa region $(83.3 \%)$, followed by the side of the tongue $(12.5 \%)$ and the dorsum of the tongue $(4.2 \%)$. In the controls, the most affected region was the alveolar ridge (52.9\%), followed by the buccal mucosa $(23.5 \%)$, dorsum of the tongue $(17.7 \%)$ and side of the tongue (5.9\%) (figure 1).

All samples of the cases and the controls were extracted and tested for the gene controlling the human $\beta$-globin gene, confirming the presence and integrity of the DNA (figure 2).

After this, the procedures for the detection of EBV by nPCR in samples of the cases and controls were performed (figures 3 and 4).

The presence of EBV was detected in $62.5 \%(15 / 24)$ and $35.3 \%(6 / 17)$ of fresh tissue samples in the cases and controls, respectively $(p=0.0899)$. In saliva samples, $75 \%(18 / 24)$ of cases and $64.7 \%(11 / 17)$ of controls were positive for EBV $(\mathrm{p}=0.4808)$. In the exfoliated cell samples, EBV was found in $70.8 \%(17 / 24)$ and $82.4 \%(14 / 17)$ of samples from the cases and controls, respectively $(\mathrm{p}=0.4033)$. For plasma, 33.3\% (8/ $24)$ and $47.1 \%(8 / 17)$ of samples from the cases and controls, respectively, were positive for $\mathrm{EBV}(\mathrm{p}=0.3806)$ (table 1$)$.

Test of proportion showed no statistically significant differences in viral positivity between the cases and controls for the studied material sources (table 2).

Table 3 Comparison of the presence of EBV in the cases between different material sources

\begin{tabular}{ll}
\hline Sources & p Value \\
\hline Saliva vs exfoliated cells & 0.6547 \\
Saliva vs tissue & 0.3657 \\
Exfoliated cells vs tissue & 0.5271 \\
Plasma vs tissue & 0.0196 * \\
Plasma vs saliva & $0.0039^{*}$ \\
Plasma vs exfoliated cells & 0.0067 * \\
\hline *Significant at the 5\% level. & \\
EBV, Epstein-Barr virus. &
\end{tabular}

Analysis of the prevalence of EBV between different material sources in patients with OLP showed a significant value for the variables: plasma versus saliva $(p=0.0039)$, plasma versus exfoliated cells $(p=0.0067)$ and plasma versus tissue $(p=0.0196)$. However, for the comparsion of saliva with exfoliated cells, saliva with tissue, and exfoliated cells with tissue the difference was not significant (table 3).

For the status of EBV in relation to the sex of patients with OLP in each source studied, statistically significant differences were found only in saliva samples $(p=0.0353)$ (table 4).

The clinical variations of the lesions found in the OLP cases were classified into two groups: (1) atrophic-erosive lesions, which include the following variables: atrophic, erosive, bullous and mixed types; and (2) non-atrophic-erosive lesions, which include lesions of the reticular, plaque and mixed types. The non-atrophic-erosive variables were the most prevalent in the cases $(54.2 \%)$ and they were also the most affected by the EBV virus. However, there were no significant differences between the clinical variations of OLP in each source material (table 5).

\section{DISCUSSION}

In this study, no statistically significant relationship was found in the positivity for EBV in tissue samples of the studied groups $(p=0.0899)$. However, the prevalence rates for the virus in these samples were higher than those found in the studies conducted by Sand et $a l^{26}$ and by Kis et $a l^{19}{ }^{19}$ which detected the presence of EBV in $26.1 \%$ and $46.6 \%$ of paraffin-embedded tissue samples from patients with OLP and in 7.3\% and $19.1 \%$ of patients without OLP, respectively, using the nPCR technique. The rate was also higher than that found by Yildirim et al, ${ }^{28}$ who found the prevalence of EBV in $35 \%$ of tissue samples from patients with OLP using immunohistochemistry.

The high viral rate found in our study, both in the cases and controls, in comparison with these studies, is believed to be due to the fact that fresh tissue was used instead of paraffinised tissues, since the use of the latter material may result in degradation of DNA due to its fixation in formalin. Another explanation might be that we used the nPCR technique, which is now known to be one of the most sensitive techniques used in molecular biology. 25

According to our research in the Pubmed database, no published studies have reported the presence of EBV in samples of tissue, exfoliated cells, saliva and plasma of patients with OLP. This is the first case-control study, with patients matched for sex and age, which involves the detection of EBV in different sources of materials from groups of patients with and without OLP.

We found a high prevalence of virus in saliva and exfoliated cell samples in both the cases and controls. However, the case-

Table 4 Relationship between the sex of the cases and the presence or absence of EBV in each of the source materials

\begin{tabular}{|c|c|c|c|c|c|c|c|}
\hline \multirow[b]{2}{*}{ Sources } & \multicolumn{3}{|l|}{ Female } & \multicolumn{3}{|l|}{ Male } & \multirow[b]{2}{*}{$\begin{array}{l}p \\
\text { Value }\end{array}$} \\
\hline & $\begin{array}{l}\text { EBV+ } \\
(\%)\end{array}$ & $\begin{array}{l}\text { EBV- } \\
(\%)\end{array}$ & $\begin{array}{l}\text { Total } \\
(\%)\end{array}$ & $\begin{array}{l}\text { EBV+ } \\
(\%)\end{array}$ & $\begin{array}{l}\text { EBV- } \\
(\%)\end{array}$ & $\begin{array}{l}\text { Total } \\
(\%)\end{array}$ & \\
\hline Tissue & $12(60)$ & $8(40)$ & $20(100)$ & $3(75)$ & $1(25)$ & $4(100)$ & 0.5138 \\
\hline Saliva & $17(85)$ & $3(15)$ & $20(100)$ & $1(25)$ & $3(75)$ & $4(100)$ & $0.0353^{*}$ \\
\hline Exfoliated cells & $15(75)$ & $5(25)$ & $20(100)$ & $2(50)$ & $2(50)$ & $4(100)$ & 0.3281 \\
\hline Blood plasma & $6(30)$ & $14(70)$ & $20(100)$ & $2(50)$ & $2(50)$ & $4(100)$ & 0.4071 \\
\hline
\end{tabular}


Table 5 Relationship between OLP clinical variables and the presence or absence of EBV in each of the source materials

\begin{tabular}{|c|c|c|c|c|c|c|c|}
\hline \multirow[b]{2}{*}{ Sources } & \multicolumn{3}{|c|}{ Variables AE } & \multicolumn{3}{|c|}{ Variables not AE } & \multirow[b]{2}{*}{ p Value } \\
\hline & EBV+ $(\%)$ & EBV- (\%) & Total (\%) & $\mathrm{EBV}+(\%)$ & EBV- (\%) & Total (\%) & \\
\hline Tissue & $9(81.8)$ & $2(18.2)$ & $11(100)$ & $6(46.2)$ & $7(53.8)$ & $13(100)$ & 0.0836 \\
\hline Saliva & $7(63.6)$ & $4(36.4)$ & $11(100)$ & $11(84.6)$ & $2(15.4)$ & $13(100)$ & 0.2393 \\
\hline Exfoliated cells & $8(72.7)$ & $3(27.3)$ & $11(100)$ & $9(69.2)$ & $4(30.8)$ & $13(100)$ & 0.6049 \\
\hline Blood plasma & $4(36.4)$ & 7 (63.6) & $11(100)$ & $4(30.8)$ & $9(69.2)$ & $13(100)$ & 0.5555 \\
\hline
\end{tabular}

control analysis for EBV status was not significant for any of these sources of materials. Comparison of the EBV detection rates in patients with OLP without lesions found in this study with the rates found in the literature, showed that they were consistent with those of Saygun et al, ${ }^{29}$ who reported that the rates of $\mathrm{EBV}$ infection in healthy individuals may vary from $0 \%$ to $100 \%$. These rates were higher than those found by Ammatuna et al, ${ }^{30}$ who obtained positivity for EBV in $15 \%$ of saliva samples and in $30 \%$ of exfoliated cell samples from healthy individuals.

Indeed, as expected, the highest EBV detection rates were found in exfoliated cell samples, and especially in saliva samples from both groups. One explanation for the high rate of EBV detection in saliva is that saliva is considered a major source of spreading the virus. However, the high viral positivity found in the exfoliated cell samples suggests that the virus may be in its replicative cycle, which may be detected in the surface layers of the epithelium. ${ }^{31}$

The use of plasma for EBV detection has been studied over the past decade, in which the EBV DNA has been shown to be a valuable diagnostic and prognostic marker for many EBV-associated malignancies, particularly nasopharyngeal carcinoma and lymphoma. ${ }^{32}$ The prevalence of EBV in blood plasma samples derived from oropharyngeal carcinomas ranges between $69 \%$ and $96 \% .{ }^{33}$ However, in individuals without malignancy this rate is lower, and ranges between $7 \%$ and $12.2 \% .^{33} 34$ In our study no significant results were found at the $5 \%$ level, on the status of EBV in blood plasma of patients in both groups. However, the detection rate of EBV in blood plasma was noted to be the lowest in the cases group, and the second lowest in the control group in comparison with the rates found in material from other sources. Moreover, we noted that plasma samples were only used concomitantly with other sources, leading us to believe that this occurred because the EBV virus is widespread in the environment, so that almost all adults have serological evidence of exposure to the virus. ${ }^{35}$ In addition, the life cycle of EBV involves two compartments (peripheral blood and oral cavity), in which the memory of the latent infection of B lymphocytes circulating in the peripheral blood constitutes a reservoir for persistent EBV. ${ }^{36}$

Regardless of the source material used or the group studied, a high prevalence of EBV DNA was found in this study because the herpesvirus family is part of the human microbiota and establishes infection throughout the life of the host. This persistent state is maintained by latent genome persistence within the host cell nucleus. $^{37}$

Of the patients studied, we found a predominance of women in both groups, which was expected for the cases, because it is in accordance with the classic characteristic of patients with OLP. These data are in agreement with the study by Sand et $a l^{26}$ who reported no differences in the prevalence of EBV between the sexes, and are in conflict with the study by Kis et $a l,{ }^{19}$ who found a prevalence of EBV in men. The relationship between the sex of patients with OLP and the prevalence of EBV in each of the sources studied was significant only in saliva samples $(p=0.0353)$. No statistically significant relationship was found for the clinical variables of OLP lesions and the presence of EBV in each of the source materials, and this result is consistent with the study by Yildirim et al. ${ }^{28}$

From the results of this study, it can be concluded that all materials tested were suitable sources for EBV detection in the two groups. Despite finding a high prevalence of EBV among the material sources tested in the two groups, no correlation was established between OLP and the EBV, and no correlation was found between the epidemiological data of the studied groups and the presence or absence of EBV.

\section{Take home messages}

- Epstein-Barr virus (EBV) detection varies according the material chosen.

- Fresh tissue, blood plasma, exfoliated cells and saliva are suitable sources for EBV detection.

- Despite the high rate of viral positivity, no relationship was found between EBV and oral lichen planus.

\section{Handling editor Runjan Chetty}

Acknowledgements The authors thank Dr Maria Lúcia Marçal Mazza Sundefeld for the statistical analysis. RdRV actively participated in all stages of research and development/revision to the manuscript; GYM who thought of the idea and participated in all stages of research and development/revision to the manuscript; LLF who participated the collection of samples and clinical trials; ERB, DGB, CMN revised the manuscript.

\section{Contributors}

Competing interests None declared.

\section{Patient consent Obtained.}

Ethics approval Approved by the ethics committee of the Araçatuba School of Dentistry by Brazil Platform (CAAE: 03069012.8.0000.5420).

Provenance and peer review Not commissioned; externally peer reviewed.

\section{REFERENCES}

1 Ismail SB, Kumar SK, Zain RB. Oral lichen planus and lichenoid reactions: etiopathogenesis, diagnosis, management and malignant transformation. J Oral Sci 2007;49:89-106.

2 Gorsky M, Epstein JB. Oral lichen planus: malignant transformation and human papilloma virus: a review of potential clinical implications. Oral Surg Oral Med Oral Pathol Oral Radiol Endod 2011;111:461-4. 
3 Sugerman PB, Savage NW, Walsh LJ, et al. The pathogenesis of oral lichen planus. Crit Rev Oral Biol Med 2002;13:350-65.

4 Cortés-Ramírez DA, Gainza-Cirauqui ML, Echebarria-Goikouria MA, et al. Oral lichenoid disease as a premalignant condition: the controversies and the unknown. Med Oral Patol Oral Cir Bucal 2009;14:E118-22.

5 Gimenez-García R, Pérez-Castrillón JL. Lichen planus and hepatitis C virus infection. $J$ Eur Acad Dermatol Venereol 2003;17:291-5.

6 Cox M, Maitland N, Scully C. Human herpes simplex-1 and papillomavirus type 16 homologous DNA sequences in normal, potentially malignant and malignant oral mucosa. Eur J Cancer B Oral Oncol 1993;29B:215-19.

7 Míco-Llorens JM, Delgado-Molina E, Baliellas-Comellas C, et al. Association between B and/or C chronic viral hepatitis and oral lichen planus. Med Oral 2004;9:183-90.

8 Oflatharta C, Flint SR, Toner M, et al. Investigation into a possible association between oral lichen planus, the human herpesviruses, and the human papillomaviruses. Mol Diagn 2003;7:73-83.

9 Andreasen J0. Oral lichen planus. 1. A clinical evaluation of 115 cases. Oral Surg Oral Med Oral Pathol 1968;25:31-42.

10 Eisen D, Carrozzo M, Bagan Sebastian JV, et al. Oral lichen planus: clinical features and management. Oral Dis 2005:11:338-49.

11 Fernández-González F, Vázquez-Álvarez R, Reboiras-López D, et al. Histopathological findings in oral lichen planus and their correlation with the clinical manifestations. Med Oral Patol Oral Cir Bucal 2011;16:e641-6.

12 Keenan AV, Ferraiolo D. Insufficient evidence for effectiveness of any treatment for oral lichen planus. Evid Based Dent 2011;12:85-6.

13 Cruchley AT, Murray PG, Niedobitek G, et al. The expression of the Epstein-Barr virus nuclear antigen (EBNA-I) in oral hairy leukoplakia. Oral Dis 1997;3(Suppl 1):S177-9.

14 Rickinson AB, Kieff ED. Epstein Barr virus. In: Knipe DM, Howley PM, Griffin DE, et al., eds. Fields virology. 5th edn. Philadelphia: Lippincott Williams \& Wilkins, 2007:2656-60.

15 Cruz I, Van den Brule AJ, Steenbergen RD, et al. Prevalence of Epstein-Barr virus in oral squamous cell carcinomas, premalignant lesions and normal mucosa-a study using the polymerase chain reaction. Oral Oncol 1997;33:182-8.

16 Faulkner GC, Krajewski AS, Crawford DH. The ins and outs of EBV infection. Trends Microbiol 2000;8:185-9.

17 Higgins CD, Swerdlow AJ, Macsween $\mathrm{KF}$, et al. A study of risk factors for acquisition of Epstein-Barr virus and its subtypes. J Infec Dis 2007;195:474-82.

18 Zimber U, Adldinger HK, Lenoir GM, et al. Geographical prevalence of two types of Epstein-Barr virus. Virology 1986;154:56-66.

19 Kis A, Fehér E, Gáll T, et al. Epstein-Barr virus prevalence in oral squamous cell cancer and in potentially malignant oral disorders in an eastern Hungarian population. Eur J Oral Sci 2009;117:536-40.

20 Cruz I, Van den Brule AJC, Brink AATP, et al. No direct role for Epstein-Barr virus in oral carcinogenesis: a study at the DNA, RNA and protein levels. Int I Cancer 2000;86:356-61.
21 Clemens MJ. Epstein-Barr virus: inhibition of apoptosis as a mechanism of cell transformation. Int J Biochmed Cell Biol 2006;38:164-9.

22 Thorley-Lawson DA, Gross A. Persistence of the Epstein-Barr virus and the origins of associated lymphomas. N Engl J Med 2004;350:1328-37.

23 Hammerschmidt W, Sugden B. Epstein-Barr virus sustains Burkitt's lymphomas and Hodgkin's disease. Trends Mol Med 2004;10:331-6.

24 Gulley ML, Tang W. Laboratory assays for Epstein-Barr virus-related disease. J Mol Diagn 2008;10:279-92.

25 Evander M, Edlund K, Boden $\mathrm{E}$, et al. Comparison of a one-step and a two-step polymerase chain reaction with degenerate general primers in a population-based study of human papillomavirus infection in young Swedish women. J Clin Microbiol 1992;30:987-92.

26 Sand LP, Jalouli J, Larsson PA, et al. Prevalence of Epstein-Barr virus in oral squamous cell carcinoma, oral lichen planus, and normal oral mucosa. Oral Surg Oral Med Oral Pathol Oral Radiol Endod 2002;93:586-92.

27 Nonogaki S, Wakamatsu A, Filho AL, et al. Molecular strategies for identifying human papillomavirus infection in routinely processed samples: focus on paraffin sections. J Low Genit Tract Dis 2005;9:219-24.

28 Yildirim B, Sengüven B, Demir C. Prevalence of herpes simplex, Epstein-Barr and human papillomaviruses in oral lichen planus. Med Oral Patol Oral Cir Bucal 2011;16:170-4

29 Saygun I, Kubar A, Ozdemir A, et al. Periodontitis lesions are a source of salivary cytomegalovirus and Epstein-Barr virus. J Periodontal Res 2005;40:187-91.

30 Ammatuna P, Capone F, Giambelluca D, et al. Detection of Epstein-Barr virus (EBV) DNA and antigens in oral mucosa of renal transplant patients without clinical evidence of oral hairy leukoplakia (OHL). J Oral Pathol Med 1998;27: 420-7.

31 Walling DM, Flaitz CM, Nichols CM, et al. Persistent productive Epstein-Barr virus replication in normal epithelial cells in vivo. J Infect Dis 2001;184: 1499-507.

32 Chan KC, Zhang J, Chan AT, et al. Molecular Characterization of Circulating EBV DNA in the Plasma of Nasopharyngeal Carcinoma and Lymphoma Patients. Cancer Res 2003:63:2028-32.

33 Chai SJ, Pua KC, Saleh A, et al. Clinical significance of plasma Epstein-Barr Virus DNA loads in a large cohort of Malaysian patients with nasopharyngeal carcinoma. J Clin Virol 2012;55:34-9.

34 Lo YM, Chan LY, Lo KW, et al. Quantitative analysis of cell-free Epstein-Barr virus DNA in plasma of patients with nasopharyngeal carcinoma. Cancer Res 1999:59:1188-91.

35 Cohen Jl. Epstein-Barr virus infection. N Eng/ J Med 2000;343:481-92.

36 Slots J, Saygun I, Sabeti M. Epstein-Barr virus in oral diseases. J Periodontal Res 2006:41:235-44.

37 Dreyfus DH. Herpesviruses and the microbiome. J Allergy Clin Immunol 2013:132:1278-86. 